\title{
The anti-genotoxic effect of some lichenic acids
}

\author{
Hamit Emre Kizil ${ }^{1}$, Selcuk Ceker ${ }^{2 *}$, Ozel Capik ${ }^{3}$ and Guleray Agar ${ }^{3}$ \\ ${ }^{1}$ Vocational School of Health Services, Bayburt University, Bayburt, Turkey. \\ ${ }^{2}$ Department of Basic Pharmaceutical Sciences, Faculty of Pharmacy, Agri Ibrahim Cecen University, Agri, Turkey. \\ ${ }^{3}$ Department of Biology, Faculty of Science, Ataturk University, Erzurum 25240, Turkey.
}

Revised: 14 September 2017; Accepted: 16 November 2017

\begin{abstract}
Four lichen secondary metabolites; diffractaic acid, lecanoric acid, lobaric acid and vulpinic acid were evaluated for the anti-genotoxic effects on human lymphocytes in vitro using single cell gel electrophoresis (SCGE) or comet assay. Carbon tetrachloride, a known mutagenic agent was used as the positive control in the comet test system. The results revealed that at all concentrations, the tested compounds mediated a significant decrease in total DNA damage (comet assay) as compared with positive controls $(p>0.05)$. The most effective doses of lichen acids were found to be $100 \mu \mathrm{gmL}^{-1}$ of diffractic acid, lobaric acid and vulpinic acid, and $50 \mu \mathrm{gmL}^{-1}$ of lecanoric acid. In addition, it was determined that the most effective among the tested compounds was vulpinic acid.
\end{abstract}

Keywords: Comet assay, diffractaic acid, lecanoric acid, lichen compounds, lobaric acid, vulpinic acid.

\section{INTRODUCTION}

Lichens are symbiotic connections between one or more inhabitant photosynthetic partners (algae or cyanobacteria) and an associated fungus. Countless studies have revealed an extensive range of biological activities of lichen secondary metabolites (Karunaratne et al., 2005; Lauinger et al., 2013). They have been used for medicinal purposes including anti-tumor, anti-bacterial, anti-fungal, anti-proliferative, antiinflammatory, anti-mutagenic, cytotoxic and antioxidant activities (Foden et al., 1975; Müller, 2001; Oksanen, 2006). On the other hand, although many of the metabolites from 60 lichen species have been studied for determining their biological properties, and diffractaic acid, lecanoric acid, lobaric acid and vulpinic acid have been purified and identified, their therapeutic potential has not yet been fully explored.

Karaosmanoglu et al. (2015) reported that doses of $200-450 \mu \mathrm{M}$ of vulpinic acid was cytotoxic and apoptotic in HepG2 and F2408 cells. Another study demonstrated that Vulpicida canadensis has a high cytotoxic effect in HepG2 and MCF-7, and vulpinic acid was determined as the major component in this lichen (FernándezMoriano et al., 2015). Recent research has shown that vulpinic acid has anti-angiogenic, anti-microbial and anti-proliferative effects (Koparal, 2015). Different researchers have emphasised that lobaric acid possessing anti-oxidant activity is also a tubulin polymerisation inhibitor (Ravaglia et al., 2014). Thadhani et al. (2012) found that lobaric acid exhibits high anti-microbial activity against Escherichia coli bacteria.

Ingólfsdóttir et al. (1998) reported that lobaric acid obtained from Stereoculon alpine has anti-microbacterial activity and anti-proliferative effects in T-47D, ZR-75-1 and K-562 cells. Şahin et al. (2015) found that Ramalina species ( $R$. farinacea, $R$. fastigiata and $R$. fraxinea) have anti-oxidant capacity, which was derived from evernic, fumarprotocetraric, lecanoric, sticic and usnic acids. Some researchers determined that evernic, vulpinic, psoromic and (+) - usnic acids have anti-parasitic and anti-fungal effects (Halama \& Van Haluwin, 2004; Lauinger et al., 2013). In another study it was shown that the diffractic acid isolated from Usnea longissima lichen

\footnotetext{
*Corresponding author (selcukceker06@gmail.com; iD https://orcid.org/0000-0002-2795-8863)
} 
has anti-hepatotoxic, anti-tumor and insecticidal effects (Karagoz et al., 2014). Also, it was found that diffractaic, usnic, norstictic and psoromic acids were cytotoxic in UACC-62 cell culture (Brandão et al., 2013).

Anti-mutagenic properties of diffractaic acid, lecanoric acid, lobaric acid and vulpinic acid have not been reported up to the present. The purpose of this study was to investigate the anti-mutagenic and mutagenic activities of the above acids using the comet assay.

\section{METHODOLOGY}

The comet assay method of Singh et al. (1988) was modified and used to determine the genotoxic effects of lichen acids.

\section{Slide preparation}

One percent normal boiling grade agarose (NMA) was prepared in $50 \mathrm{~mL}$ PBS solution and $80 \mu \mathrm{L}$ of NMA was dropped to each well on the slide. One percent low melting grade agarose (LMA) was also prepared in $50 \mathrm{~mL}$ PBS solution. The prepared LMA solution was placed in $5 \mathrm{~mL}$ volumes in the balcony tubes and stored at $+4{ }^{\circ} \mathrm{C}$.

\section{Blood sampling}

Heparinised human blood from 4 healthy non-smoking donors between age of 25 and 30, with no history of $\mathrm{X}$-ray exposure and antibiotic treatment was used. The donors also signed informed consent forms. Lymphocytes were obtained by ficoll density centrifugation method from heparinised whole blood. Histopaque $(600 \mathrm{~mL})$ was added onto $1 \mathrm{~mL}$ of peripheral blood diluted with PBS. After centrifugation, the supernatant was discarded and 1640-RPMI medium was added onto the pellet. Ten milliliter samples (approximately 10000 lymphocytes) were separated and $20 \mu \mathrm{L}$ trypan blue solution was added. The number of cells in the haemocytometer was calculated. $\mathrm{CCl}_{4}$ (in concentrations of $5 \mu \mathrm{M}$ ) and lichen acids were added to the cultures. The experiments were performed on 7 groups as follows:

Culture 1: Control

Culture 2: $5 \mu \mathrm{M} \mathrm{CCl}_{4}$

Culture 3: $25 \mu \mathrm{gmL}^{-1}$ lichen acids

Culture 4: $5 \mu \mathrm{M} \mathrm{CCl}_{4}+12.5 \mu \mathrm{gmL}^{-1}$ lichen acids

Culture 5: $5 \mu \mathrm{M} \mathrm{CCl}_{4}+25 \mu \mathrm{gmL}^{-1}$ lichen acids

Culture 6: $5 \mu \mathrm{M} \mathrm{CCl}_{4}+50 \mu \mathrm{gmL}^{-1}$ lichen acids

Culture 7: $5 \mu \mathrm{M} \mathrm{CCl}_{4}+100 \mu \mathrm{gmL}^{-1}$ lichen acids
For comet demonstration, the cultures were incubated at $37^{\circ} \mathrm{C}$ for $3 \mathrm{~h}$. The pellets obtained after centrifugation were suspended in $100 \mu \mathrm{L}$ PBS. Then $100 \mu \mathrm{L}$ of LMA solution was added to the suspension. Agar was mixed with lymphocytes by pipetting immediately before solidification and $80 \mu \mathrm{L}$ of this final mixture was spread over previously prepared slides. It was covered with lamella and kept in the refrigerator for $10 \mathrm{~min}$. The coverslip was slowly removed from the slides, removed from the refrigerator and $90 \mu \mathrm{L}$ LMA was added. The slides were closed again for $25 \mathrm{~min}$ and after the slides were dried, the cell and nucleus were lysed. After the lysing phase, the slides were left in alkaline electrophoresis buffer for $30 \mathrm{~min}$ to separate the DNA strands. Subsequently, the DNAs were run in the buffer solution at $300 \mathrm{~mA}, 24$ volts for $30 \mathrm{~min}$. All of these operations were done in yellow light. The slides were then neutralised. After the neutralisation process was completed, the comets were counted by staining. Ethidium bromide stain $\left(5 \mu \mathrm{gmL}^{-1}\right)$, a fluorescent dye, was used for staining. For each slide, $80 \mu \mathrm{L}$ of dye was added, and 100 DNA images were evaluated with a 40-magnification fluorescent microscope to asses DNA damage. DNA damage was examined at a scale of 0 to 4 according to the formation of the tail (Collins, 2004). The scale used was as follows: 0 , no tail; 1 , comet tail $<$ half the width of the nucleus; 2 , comet tail equal to the width of the nucleus; 3 , comet tail longer than the nucleus; 4 , comet $>$ twice the width of the nucleus. The visual score for each class was calculated by multiplying the percentage of cells in the appropriate comet class by the value of the class. The total visual comet score characterising the degree of DNA damage in the entire study groups was the sum of the scores in the five comet classes. Thus, the total visual score could range from 0 (all undamaged) to 400 (all maximally damaged) arbitrary units (AU), as reported by Collins (2004).

\section{Statistical analysis}

The statistical analysis of comet results was performed using the Mann-Whitney U-test and one-way ANOVA. A level of probability of $p<0.05$ was taken as indicating statistical significance. All experiments were performed in three replicates and data was compared for reproducibility. For these procedures, SPSS v15.0 version for Windows was used. The results are expressed as the mean $\pm \mathrm{SE}$.

\section{RESULTS AND DISCUSSION}

Mutagenic and anti-mutagenic effects of diffractaic, lecanoric, lobaric and vulpinic acids were examined by using comet assay test systems and a single dose of $\mathrm{CCl}_{4}$, 
Table 1: The effects of lichenic acids and $\mathrm{CCl}_{4}$ on comet assay

\begin{tabular}{|c|c|c|c|c|}
\hline & \multicolumn{4}{|c|}{ DNA damage level } \\
\hline & Diffractaic acid & Lecanoric acid & Lobaric acid & Vulpinic acid \\
\hline Control & $6.72 \pm 0.64^{\mathrm{a}}$ & $6.72 \pm 0.64^{\mathrm{a}}$ & $6.72 \pm 0.64^{\mathrm{a}}$ & $6.72 \pm 0.64^{\mathrm{a}}$ \\
\hline $\mathrm{CCl}_{4}(5 \mu \mathrm{M})$ & $116.35 \pm 1.28^{\mathrm{e}}$ & $116.35 \pm 1.28^{\mathrm{e}}$ & $116.35 \pm 1.28^{\mathrm{e}}$ & $116.35 \pm 1.28^{\mathrm{e}}$ \\
\hline Lichen acid $\left(25 \mu \mathrm{gmL}^{-1}\right)$ & $12.20 \pm 0.45^{\mathrm{ab}}$ & $19.48 \pm 0.36^{\mathrm{ab}}$ & $17.26 \pm 0.86^{\mathrm{ab}}$ & $11.26 \pm 0.96^{\mathrm{a}}$ \\
\hline Lichen acid $\left(12.5 \mu \mathrm{gmL}^{-1}\right)+\mathrm{CCl}_{4}(5 \mu \mathrm{M})$ & $97.08 \pm 0.17^{\mathrm{de}}$ & $102.26 \pm 0.90^{\mathrm{e}}$ & $91.42 \pm 1.58^{\mathrm{de}}$ & $73.38 \pm 1.26^{\mathrm{cc}}$ \\
\hline Lichen acid $\left(25 \mu \mathrm{gmL}^{-1}\right)+\mathrm{CCl}_{4}(5 \mu \mathrm{M})$ & $93.36 \pm 1.23^{\mathrm{d}}$ & $94.60 \pm 0.42^{\mathrm{d}}$ & $82.12 \pm 0.74^{\mathrm{d}}$ & $61.78 \pm 0.78^{\mathrm{c}}$ \\
\hline Lichen acid $\left(50 \mu \mathrm{gmL}^{-1}\right)+\mathrm{CCl}_{4} \quad(5 \mu \mathrm{M})$ & $80.10 \pm 2.26^{\mathrm{c}}$ & $78.46 \pm 1.30^{\mathrm{cd}}$ & $79.30 \pm 1.62^{\mathrm{d}}$ & $39.12 \pm 1.92^{\mathrm{b}}$ \\
\hline Lichen acid $\left(100 \mu \mathrm{gmL}^{-1}\right)+\mathrm{CCl}_{4}(5 \mu \mathrm{M})$ & $76.03 \pm 1.52^{\text {cd }}$ & $82.40 \pm 0.15^{\mathrm{d}}$ & $74.12 \pm 0.84^{\mathrm{cd}}$ & $26.58 \pm 0.32^{\mathrm{ab}}$ \\
\hline
\end{tabular}

Carbon tetrachloride $\left(\mathrm{CCL}_{4}\right)$ was used as positive control for human blood cells. Values of DNA damage level (a, b, c, d, e) are significantly different compared to negative control $(\mathrm{p}<0.05)$

which is a known mutagenic agent. A single dose of $\mathrm{CCl}_{4}$ caused a significant increase in DNA strand breaks that lead to DNA migration. All tested concentrations of metabolites were not found to be mutagenic or toxic to human lymphocyte cells. According to the findings of this study, it was evident that exposure to the four metabolites significantly decreased the mutagenic activities.

As evident from Table 1, the most effective doses of lichen acids were found to be diffractic, lobaric, vulpinic acid $\left(100 \mu \mathrm{gmL}^{-1}\right)$ and lecanoric acid $\left(50 \mu \mathrm{gmL}^{-1}\right)$. In addition, it was determined that the most effective lichen acid is vulpinic acid when compared with the negative control. However, the DNA damage decreased progressively with increased diffractic acid, lobaric acid and vulpinic acid concentration. The $50 \mu_{\mathrm{gmL}^{-1}}$ concentration of lecanoric acid was the most effective dose against DNA damage as mentioned above. The effects of diffractic acid on the frequencies of total chromosomal aberration and the micronucleus have been reported earlier (Demir et al., 2015). In addition, researchers have reported that diffractic acid isolated from Usnea longissima lichen has anti-hepatotoxic, anti-tumor and cytotoxic effects (Emsen et al., 2012; Brandão et al., 2013; Karagoz et al., 2014; 2015). It has also been found that diffractic acid from Usnea longissima lichen has antiulcerogenic properties obtained against indocyanineinduced gastric lesions formed in rats (Bayir et al., 2006). In addition, some investigators have found changes in anti-proliferative activity and reactive oxygen species (ROS) levels in MCF-7, HeLa, and HCT-116 cell lines exposed to different concentrations ranging from $2.5-$ $100 \mu \mathrm{M}$ diffractic acid and determined that they mediate concentration dependent cytotoxicity (Brisdelli et al., 2013).
The studies with vulpinic acid revealed cytotoxic and apoptotic activities in HepG2, MCF-7 and F2408 cells, in addition to their anti-inflammatory, anti-angiogenic, antimicrobial and anti-proliferative activities (Foden et al., 1975; Fernández-Moriano et al., 2015; Karaosmanoğlu et al., 2015; Koparal, 2015).

The present study describes for the first time the antimutagenic effects of lecanoric, lobaric and vulpinic acids. Recently, several studies have demonstrated that lobaric acid possesses anti-microbial activity, anti-proliferative effects and anti-oxidant activity (Ingólfsdóttir et al., 1998; Haraldsdóttir et al., 2004; Thadhani et al., 2011).

$\mathrm{CCl}_{4}$, a known mutagenic agent was used as the positive control in the comet test system. A single dose

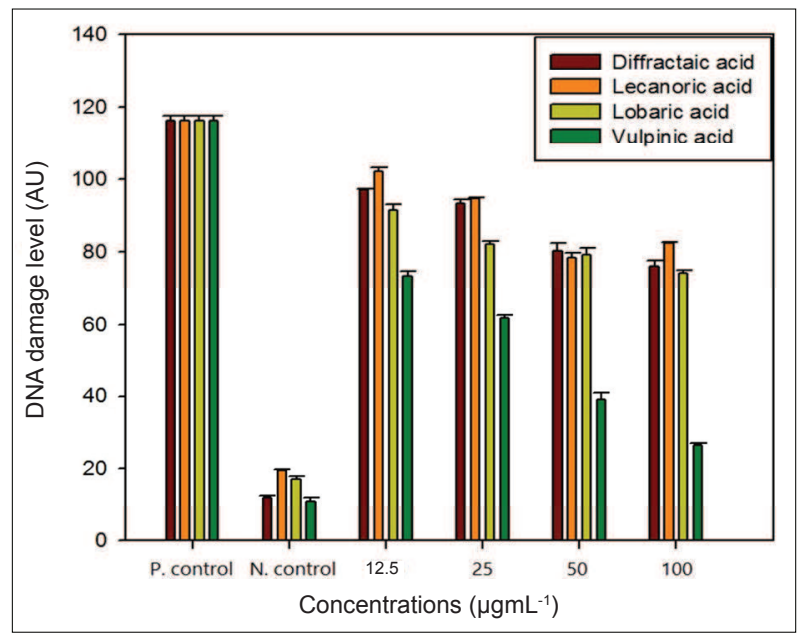

Figure 1: The effects of lichenic acids and $\mathrm{CCl}_{4}$ on comet assay 
of $\mathrm{CCl}_{4}$ caused a significant increase in DNA strand breaks that lead to DNA migration. On the other hand, the comet tail lengths were reduced by different doses of lichen acid. The most effective doses of lichen acids were found as $100 \mu \mathrm{gmL}^{-1}$ diffractic acid, lobaric acid, and vulpinic acid and $50 \mu \mathrm{gmL}^{-1}$ lecanoric acid as seen in Table 1 and Figure 1. In addition, it was determined that the most effective lichen acid is vulpinic acid when compared with the negative control.

\section{CONCLUSION}

Based on the results obtained in the present study and those obtained in the investigations described above, the anti-mutagenic effect of the four lichen acids (diffractaic acid, lecanoric acid, lobaric acid and vulpinic acid) could be related to their antioxidants concentrations. This view is supported by the data obtained in recent investigations carried out in the laboratory. These studies indicate that the above mentioned four lichen acids could increase the levels of glutathione (GSH) and superoxide dismutase (SOD) and glutathione peroxidase (GPx) enzymes and decrease the level of malondialdehyde (MDA) in human lymphocytes in vitro.

\section{REFERENCES}

1. Bayir Y., Odabasoglu F., Cakir A., Aslan A., Suleyman H., Halici M. \& Kazaz C. (2006). The inhibition of gastric mucosal lesion, oxidative stress and neutrophilinfiltration in rats by the lichen constituent diffractaic acid. Phytomedicine 13(8): $584-590$.

DOI: https://doi.org/10.1002/ptr.4739ps://doi.org/10.1016/ j.phymed.2005.07.002

2. Brandão L.F.G., Alcantara G.B., Matos M.D.F.C., Bogo D., Freitas D.S., Oyama N.M. \& Honda N.K. (2013). Cytotoxic evaluation of phenolic compounds from lichens against melanoma cells. Chemical and Pharmaceutical Bulletin 61(2): $176-183$.

DOI: https://doi.org/10.1248/cpb.c12-00739

3. Brisdelli F., Perilli M., Sellitri D., Piovano M., Garbarino J.A., Nicoletti M. \& Celenza G. (2013). Cytotoxic activity and antioxidant capacity of purified lichen metabolites: an in vitro study. Phytotherapy Research 27(3): $431-437$. DOI: https://doi.org/10.1002/ptr.4739

4. Collins A.R. (2004). The comet assay for DNA damage and repair. Molecular Biotechnology 26(3): 249 - 261.

DOI: https://doi.org/10.1385/MB:26:3:249

5. Demir L., Togar B., Turkez H., Sozio P., Aslan A. \& Di Stefano A. (2015). The investigation of cytogenetic and oxidative effects of diffractaic acid on human lymphocyte cultures. Brazilian Archives of Biology and Technology 58(1): $75-81$.

DOI: https://doi.org/10.1590/S1516-8913201502752
6. Emsen B., Bulak Y., Yıldrım E., Aslan A. \& Ercisli S. (2012). Activities of two major lichen compounds, diffractaic acid and usnic acid against Leptinotarsa decemlineata Say, 1824 (Coleoptera: Chrysomelidae). Egyptian Journal of Biological Pest Control 22(1): 5 - 10.

7. Fernández-Moriano C., Divakar P.K., Crespo A. \& Gómez-Serranillos M.P. (2015). Neuroprotective activity and cytotoxic potential of two Parmeliaceae lichens: identification of active compounds. Phytomedicine 22(9): $847-855$.

DOI: https://doi.org/10.1016/j.phymed.2015.06.005

8. Foden F., McCormick J. \& O'Mant D. (1975). Vulpinic acids as potential antiinflammatory agents. 1. Vulpinic acids with substituents in the aromatic rings. Journal of Medicinal Chemistry 18(2): 199 - 203.

DOI: https://doi.org/10.1021/jm00236a020

9. Halama P. \& Van Haluwin C. (2004). Antifungal activity of lichen extracts and lichenic acids. BioControl 49: 95 - 107.

10. Haraldsdóttir S., Guolaugsdóttir E., Ingólfsdóttir K. \& OgmundsdóttirHM. (2004). Anti-proliferative effects of lichen-derived lipoxygenase inhibitors on twelve human cancer cell lines of different tissue origin in vitro. Planta Medica 70: 1098 - 1100 .

DOI: https://doi.org/10.1055/s-2004-832657

11. Ingólfsdóttir K., Chung G.A., Skúlason V.G., Gissurarson S.R. \& Vilhelmsdóttir M. (1998). Antimycobacterial activity of lichen metabolites in vitro. European Journal of Pharmaceutical Sciences 6(2): 141 - 144.

12. Karagoz I., Ozaslan M., Guler I., Uyar C., Yalim T., Kazanci U. \& Cakir A. (2014). In vivo antitumoral effect of diffractaic acid from lichen metabolites on Swiss albino mice with Ehrlich ascites carcinoma: an experimental study. International Journal of Pharmacology 10(6): 307 - 314. DOI: https://doi.org/10.3923/ijp.2014.307.314

13. Karagoz I.D., Ozaslan M., Kilic I.H., Guler I., Uyar C., Tuter D. \& Gezici S. (2015). Hepatoprotective effect of diffractaic acid on carbon tetrachloride-induced liver damage in rats. Biotechnology and Biotechnological Equipment 29(5): 1011 - 1016.

DOI: https://doi.org/10.1080/13102818.2015.1056754

14. Karaosmanoğlu O., Sivas H., Tay T. \& Türk A.Ö. (2015). The in vitro investigation of cytotoxic and apoptotic effects vulpinic acid on normal and cancer cells. Journal of Biotechnology 208:595.

DOI: https://doi.org/10.1016/j.jbiotec.2015.06.299

15. Karunaratne V., Bombuwela K., Kathirgamanathar S. \& Thadhani V.M. (2005). Lichens: a chemically important biota. Journal of the National Science Foundation of Sri Lanka 33(3): 169 - 186.

DOI: https://doi.org/10.4038/jnsfsr.v33i3.2323

16. Koparal A.T. (2015). Anti-angiogenic and antiproliferative properties of the lichen substances (-)-usnic acid and vulpinic acid. Zeitschrift für Naturforschung C 70(5-6): $159-164$.

DOI: https://doi.org/10.1515/znc-2014-4178

17. Lauinger I.L. et al., (15 authors) (2013). Potential of lichen secondary metabolites against Plasmodium liver stage parasites with FAS-II as the potential target. Journal of 
Natural Products 76(6): 1064 - 1070.

DOI: https://doi.org/10.1021/np400083k

18. Müller K. (2001). Pharmaceutically relevant metabolites from lichens. Applied Microbiology and Biotechnology 56(1-2): $9-16$.

DOI: https://doi.org/10.1007/s002530100684

19. Oksanen I. (2006). Ecological and biotechnological aspects of lichens. Applied Microbiology and Biotechnology 73(4): $723-734$.

DOI: https://doi.org/10.1007/s00253-006-0611-3

20. Ravaglia L.M., Gonçalves K., Oyama N.M., Coelho R.G., Spielmann A.A. \& Honda N.K. (2014). In vitro radicalscavenging activity, toxicity against $A$. salina, and $\mathrm{nmr}$ profiles of extracts of lichens collected from Brazil and Antarctica. Química Nova 37(6): 1015 - 1021.

21. Şahin S., Oran S., Şahintürk P., Demir C. \& Öztürk Ş. (2015). Ramalina lichens and their major metabolites as possible natural antioxidant and antimicrobial agents. Journal of Food Biochemistry 39(4): 471 - 477.

DOI: https://doi.org/10.1111/jfbc.12142

22. Singh N.P., McCoy M.T., Tice R.R. \& Schneider E.L. (1988). A simple technique for quantitation of low levels of DNA damage in individual cells. Experimental Cell Research 175(1): $184-191$.

23. Thadhani V.M., Choudhary M.I., Ali S., Omar I., Siddique H. \& Karunaratne V. (2011). Antioxidant activity of some lichen metabolites. Natural Product Research 25(19): 1827 $-1837$.

DOI: https://doi.org/10.1080/14786419.2010.529546

24. Thadhani V.M., Choudhary M.I., Khan S. \& Karunaratne V. (2012). Antimicrobial and toxicological activities of some depsides and depsidones. Journal of the National Science Foundation of Sri Lanka 40(1): 43 - 48.

DOI: https://doi.org/10.4038/jnsfsr.v40i1.4167 